\title{
Deregulating Through the Back Door: The Hard Way to Fight a Revolution
}

\author{
Abner J. Mikva †
}

Elections do not amend, repeal, or modify statutes:

-not even when the impact of such statutes is a prominent issue in the campaign;

-not even when the candidate championing changes in the statutes wins an overwhelming victory.

This truism should not have to be explained to students of the law. But the popular perception is so to the contrary that it has generated political consequences that may trump the rule of law. The 1980 national election and its impact on the administrative state is the clearest example.

In 1981, President Ronald Reagan initiated a program of changing or eliminating regulations, just as he had promised in his campaign and inaugural address. He was assisted by a comprehensive Heritage Foundation study ${ }^{1}$ that recommended efficacious changes, department by department and agency by agency. Before six months of the Reagan presidency had passed, 180 regulations had been withdrawn, modified, or delayed; half as many rules were being proposed as compared to the previous year; and the Federal Register, the daily record of all new regulations, had lost one-third of its volume. ${ }^{2}$

But in its haste to implement the deregulation mandate, the Reagan Administration forgot about the Congress. This oversight resulted in a classic demonstration of de Tocqueville's proposition: "There is hardly a political question in the United States which does not sooner or later turn into a judicial one." As the Adminis-

$\dagger$ Judge, United States Court of Appeals for the District of Columbia Circuit. The notes accompanying this article are citations to authority and contain nothing of substance. See Abner J. Mikva, Goodbye to Footnotes, 56 U Colo L Rev 647 (1985).

${ }^{1}$ Charles L. Heatherly, ed, Mandate for Leadership: Policy Management in a Conservative Administration (Heritage Foundation, 1981).

2 Susan J. Tolchin and Martin Tolchin, Presidential Power Over the Regulatory Process, in Gregory A. Daneke and David J. Lemak, eds, Regulatory Reform Reconsidered 57, 72 (Westview Press, 1985).

${ }^{3}$ Alexis de Tocqueville, Democracy in America 248 (Harper \& Row, 1966), edited by J. 
tration sometimes ignored the requirements of the Administrative Procedure Act (APA) ${ }^{4}$ (which governs agencies' use of congressionally delegated power), and sometimes acted inconsistently with duly enacted laws requiring regulation, much time and money went into court battles that could have been avoided had the Administration integrated its efforts with the congressional agenda. A look at the Administration's stumble informs our understanding of the workings of the administrative state.

\section{Early Rumblings}

The tide of deregulation began to sweep into Washington long before the 1980 election. As early as 1962, John F. Kennedy called for "greater reliance on the forces of competition and less reliance on the restraints of regulation."

President Kennedy sought to reverse the growth in the federal bureaucracy that had begun with the New Deal. At least through 1948 , most Democrats won national elections by advocating greater federal involvement in the market and other forums. For almost twenty years, most Americans believed that the federal government was a positive force in promoting "the good life." The legitimate domain of federal regulation was thought to include everything from housing and transportation to toy design and the provision of recreational areas. The thin voices complaining about a "growing bureaucracy" were answered by polemics like that of former Vice President Alben Barkley, who declared: "A bureaucrat is a Democrat who holds some office that a Republican wants."6 Such statements not only brought the faithful to their feet; they also persuaded the neutrals to continue supporting the New Deal and government activism.

In the 1950s and 1960s, the complaints about bureaucrats and the shape of their heads became loud enough to vie with Vice President Barkley's put-down of the dissenters. A bureaucrat became somebody who interpreted and enforced federal statutes mindlessly. Initially, academics were the primary voices of concern about the impact of regulation on the economy. Richard Caves produced the first major investigation of airline industry regulation in 1962 and concluded that "[w]ithout regulation, more flexibility

\footnotetext{
P. Mayer and Max Lerner, translated by George Lawrence.

- 5 USC $\$ 551.706$ (1988).

5 Ann F. Friedlaender, The Dilemma of Freight Transport Regulation vii (Brookings Institution, 1969).

${ }^{6}$ Michael Jackman, Crown's Book of Political Quotations 14 (Crown, 1982).
} 
and possibly more variety would exist in the range of product and price offered to the traveler." Similarly, a group of economists studying competition in the transportation industry observed that

years of public regulation have stifled managerial incentives and imagination. At the same time, technological developments have radically changed the competitive relationships between the different transportation sectors. Monopoly or partial monopoly has become the exception rather than the rule in transportation $\ldots .^{8}$

In 1970, the academy's concern with the economic effects of regulation became a national concern when the nation's biggest railroad, the Penn Central, collapsed from the strain of trying to reach all the areas that the Interstate Commerce Commission required it to serve. ${ }^{9}$ Not surprisingly, President Nixon's Council of Economic Advisers argued for transportation industry deregulation, reporting to the President in 1971 that "regulation appears to have promoted high freight rates and numerous inefficiencies."10 The deregulatory spirit was not limited to the Republicans. Whereas in 1959 Senator Estes Kefauver responded to evidence of excessive profits and price gouging in the pharmaceutical industry by proposing regulation, ${ }^{11}$ evidence of similar abuses in the airline industry-including prices estimated by some experts to be as much as one hundred percent higher than the market warranted-was greeted by Senator Edward M. Kennedy with support for deregulation. When faced with the choice in 1974 between investigating airline abuses or examining possible procedural reforms suggested by the Watergate affair, Senator Kennedy chose to probe the air transport issues as a more profitable use of his Senate time. ${ }^{12}$

It became clear at many political levels that the public's love affair with federal regulation was cooling. The rhetoric of the national campaigns, starting with the 1952 presidential election,

? Richard E. Caves, Air Transport and Its Regulators 431 (Harvard, 1962).

8 John R. Meyer, Merton J. Peck, John Stenason, and Charles Zwick, The Economics of Competition in the Transportation Industries 13 (Harvard, 1959).

- Martha Derthick and Paul J. Quirk, The Politics of Deregulation 38 (Brookings Institution, 1985).

10 The Annual Report of the Council of Economic Advisers, in Economic Report of the President 11, 125 (GPO, 1971). See also Derthick and Quirk, The Politics of Deregulation at 37 (cited in note 9 ).

"Comment, OMB Involvement in FDA Drug Regulations: Regulating the Regulators, 38 Cath U L Rev 175, 180 n 25 (1988).

12 Derthick and Quirk, The Politics of Deregulation at 40-41 (cited in note 9). 
changed markedly. While the Republicans had a head start and a better public image on the issue of deregulation, Democrats strived to catch up. By the 1976 election, Jimmy Carter was on the offensive about deregulation, talking of sunset provisions for regulations and zero-based budgeting as means to control the federal beast. ${ }^{13}$

While deregulation was an appealing issue, it was not a politically pressing one. Consequently, neither Presidents Ford nor Carter felt great pressure to achieve dramatic results quickly. Indeed, while both the Ford and Carter Administrations formulated major deregulatory plans, they also extended regulation into new areas. They implemented much of the environmental and safety legislation now on the books, which was to be cited as evidence of alleged regulatory excesses during the campaigns of the 1980s. By the 1980 election, the rhetoric had changed dramatically, but the federal government was larger and more pervasive than ever before.

The stage was set for a "Get the government off our backs" campaign, and Ronald Reagan won an overwhelming mandate to do just that. In a campaign speech delivered in Youngstown, Ohio, candidate Reagan

blamed empty steel mills and long lines of unemployed on EPA zeal. Speaking to workers there, Reagan attacked [the Environmental Protection Agency (EPA)] . . . EPA officials have gone beyond guidelines for protecting the environment, said Reagan. "In reality, what they believe in is no growth."14 After winning on this platform, President Reagan announced deregulation as a goal in his inaugural address, proclaiming:

Now, so there will be no misunderstanding, it's not my intention to do away with government. It is rather to make it work-work with us, not over us; to stand by our side, not ride on our back. Government can and must provide opportunity, not smother it; foster productivity, not stifle it. ${ }^{15}$

\section{The Proper Method}

With the election won, the question became how Reagan should implement his deregulatory mandate. A simplistic view of

\footnotetext{
13. See David S. Broder, Senate "Sunset" Bill Has Administration's Cautious Support, Wash Post A2, col 5 (March 23, 1977).

14 Rowland Evans and Robert Novak, The Reagan Revolution 142 (E. P. Dutton, 1981).

15 Id at 138-39 (quoting President Reagan's first inaugural address, January 20, 1981).
} 
the allocation of responsibility in the federal government would suggest that the President, as the chief executive officer, can cut and prune the executive branch as he sees fit. Congress passes the laws, the courts interpret the laws, and the President enforces the laws. As the enforcer, the President should be able to decide how, when, and to whom he delegates his responsibility, and what enforcement tasks should have priority. The appeal of such an analysis is obvious. The President is the only federal official elected nationally; he can rise above the parochial and political interests that may hold sway in Congress. Judges, for their part, should not decide the merits of federal regulation because such determinations are policy decisions rather than legal decisions. The difficulty with this separation of powers analysis is, as usual, the Constitution.

Whatever the popularity of the notion that the three branches of government are separate but equal, the Constitution has never been construed that way. Marbury $v$ Madison ${ }^{16}$ established the courts as the primary and final arbiters of congressional statutes and the Constitution. The Steel Seizure Case ${ }^{17}$ (which treated the constitutional command that the President "take Care that the Laws be faithfully executed" as a restriction, not a license) and the Pocket Veto Case $^{18}$ (holding that Congress may "re-pass [a] bill over [the President's] objections") established the primacy of Congress in battles with the President over the shape of the government and the scope of laws. The Constitution leaves no doubt that Congress is to make the basic policy decisions with respect to regulatory schemes, subject to the President's approval; and even if congressional decisions are vetoed by the President, they become law if repassed by two-thirds of the Congress.

The courts have long held that Congress has broad powers to prevent attempts to sidestep its authority. In Kennedy $v$ Sampson ${ }^{19}$ for example, the D.C. Circuit held that the President's use of a "pocket veto" to prevent Congress from overriding a veto was subject to Congress's prerogative to consider presidential messages during the recess.

Congress's power to implement its acts has also been confirmed by cases on presidential impoundment and sequestration of

\footnotetext{
165 US (1 Cranch) 137 (1803).

17 Youngstown Sheet \& Tube Co. v Sawyer, 343 US 579, 587 (1952) (quoting US Const, Art II, § 3).

${ }^{18} 279$ US 655,678 (1929).

19511 F2d 430 (DC Cir 1974).
} 
appropriated money. In Dabney $v$ Reagan, ${ }^{20}$ for example, President Reagan refused to spend money allocated to the Solar Energy and Energy Conservation Bank. The court "ORDERED ... that defendant[] Reagan ... make those funds appropriated for Bank use for F[iscal Year] 1982 available for disbursement ...."21 These cases illustrate the principle that Congress makes the laws, and the executive branch must enforce them as written. ${ }^{22}$

Even when Congress has recognized the advantage of decisionmaking by full time experts and has delegated power to the executive branch, the delegated power is not absolute. The President and his proxies at the agencies must follow Congress's guidelines and intent: "If the intent of Congress is clear, that is the end of the matter; ... [ $t$ ] he agency must give effect to the unambiguously expressed intent of Congress." ${ }^{23}$ Additionally, the agency may act only upon a reasonable construction of congressional goals, ${ }^{24}$ and an administrative construction of a statute will not survive judicial review if it "frustrate[s] the policy that Congress sought to implement," or is "inconsistent with the statutory mandate."25

In spite of these constraints, Presidents have always been tempted to go it alone. The sirens luring our Presidents toward exclusive control of federal agencies are conspicuous: freedom from congressional input and disagreement; the desire to avoid public battles with the legislature over proposed new rules; and perhaps even the ability to bypass legislative bodies composed predominantly of political or ideological opponents. In short, many Presidents and their staffs conclude that it is far easier to run the country without congressional interference-a view that is widely held by the new monarchists who populate some of the conservative and neo-conservative think tanks, but that does not happen to correspond with our constitutional arrangement. (During my time in the Illinois legislature, I handled some deregulatory bills for the late Governor Kerner. The bills passed the House easily, but were killed in the state Senate. I told the Governor that it was enough

20 542 F Supp 756, 768 (SD NY 1982).

${ }^{21}$ Id (emphasis in original).

${ }^{22}$ For other cases illustrating this principle, see Louisiana ex rel Guste v Brinegar, 388 F Supp 1319, 1325 (D DC 1975); and Community Action Programs v Ash, 365 F Supp 1355, 1360-61 (D NJ 1973).

${ }^{23}$ Chevron U.S.A., Inc. v Natural Resources Defense Council, Inc., 467 US 837, 842-43 (1984).

24 Id at 845.

${ }^{25}$ Securities Industry Association v Board of Governors of the Federal Reserve System, 468 US 137, 143 (1984), citing Federal Election Commission v Democratic Senatorial Campaign Committee, 454 US 27, 32 (1981). 
to turn me into a unicameralist. He eyed me stonily, and said, "That would solve half the problem.")

The Constitution mandates the legislative route to deregulation. Moreover, this route is faster and more practical. The best way to see this is to "look at the record"-i.e., the Reagan Administration's attempts to bypass this route. The next section describes the route taken by the Reagan Administration, as background for evaluating the effects and pitfalls of this approach.

\section{President Reagan's Controversial Implementation of SHaRed Goals}

At least since Gerald Ford proclaimed deregulation to be a domestic priority, Presidents and members of Congress have viewed reduction in federal oversight and regulation as ways of improving the economy and addressing the complaints of the adversely affected:

"Rules and regulations churned out by federal agencies were having a damaging effect on almost every aspect of American life," Ford wrote in his memoirs . . . . Jimmy Carter wrote in his memoirs of the "problem of the federal bureaucracy-its complexity, its remoteness when people needed help, its intrusiveness when they wanted to be left alone, and its excessive regulation of the major industries to the detriment of consumers." Carter's successor, Ronald Reagan, had been campaigning for years against big government and bureaucratic excess and entered office pledged to strong, swift action against "overregulation."26

While leaders from across the political spectrum called for deregulation, they rarely agreed on what or how to deregulate. Senator Kennedy stressed pro-consumer values such as lower prices and better services as he sought to deregulate the airline industry, while President Ford stressed free enterprise, business concerns, and the troubles caused by big government. ${ }^{27}$ President Carter was most concerned with deregulating the transportation and communication-related industries, while President Reagan generally advocated deregulating everything touched by government, including health, safety, and the environment. ${ }^{28}$

${ }^{28}$ Derthick and Quirk, The Politics of Deregulation at 29-30 (cited in note 9) (footnotes omitted).

${ }^{27}$ Id at 41,47 .

${ }^{28}$ Id at 33-34. 
When Presidents set their sights on redirecting the rules and efforts of a federal agency, they should not be surprised that the proposed changes generate opposition from some citizens and their congressional representatives. Even if the executive and legislative branches agree on goals, they may disagree on means. Tension inevitably arises between the two political branches when the deregulation bell sounds.

This tension existed even during the more moderate deregulatory climate prior to the 1980 election. During the Carter Administration, the Civil Aeronautics Board (CAB) took steps to encourage airline competition. Dissatisfied with the pace or shape of the CAB's efforts, Congress took over the deregulation of the airlines, enacting the Airline Deregulation Act of $1978^{29}$ and eliminating the CAB outright. ${ }^{30}$ Similarly, the Interstate Commerce Commission, long the scapegoat of attacks on the bloated bureaucracy, tried from 1976 to 1980 to cut back trucking regulations and make it easier for firms to enter the industry. Again, neither the pace nor the form of deregulation satisfied Congress, which took over the efforts and passed the Motor Carrier Act of $1980 .^{31}$

Almost as if preparing for the major strife ahead, Congress began frequently to use legislative vetoes to exercise an independent role in the deregulation efforts. Conceived in the 1930s, a legislative veto is a statutory provision that reserves to Congress or its committees the power to invalidate, without presentment, executive or agency action that is otherwise authorized. Congress included legislative vetoes in as many bills in the first half of the 1970 s as during the previous four decades. ${ }^{32}$ In the post-Watergate power struggle between the President and the Congress, the legislative veto became more prevalent than ever. Congressman Elliott Levitas went so far as to propose a general legislative veto that would cover all agency powers governed by the APA. ${ }^{33} \mathrm{He}$ explained that the founders of the Constitution would look at Congress's diminished authority and ask, "How did it happen that the very things we fought for-control over the executive by the people

29 Id at 5 .

30 See Albert R. Karr, CAB Sheds Workers as it Prepares to Fly Slowly into Sunset, Wall St J 1, col 4 (Nov 11, 1980).

31 Derthick and Quirk, The Politics of Deregulation at 6 (cited in note 9).

${ }^{32}$ Barbara H. Craig, Chadha 36 (Oxford, 1988).

${ }^{33}$ Id at 44 (citing House Committee on the Judiciary, Subcommittee on Administrative Law and Governmental Relations, Hearings on Congressional Review of Administrative Rulemaking, 94th Cong, 1st Sess 142-43, 150) (1975) (testimony of Representative Elliott Levitas). 
through their representatives" could be lost to a fourth, "non-Constitutional," branch of government? ${ }^{34}$ Until the Supreme Court held legislative vetoes unconstitutional in INS v Chadha, ${ }^{35}$ Congress inserted the provisions in appropriation and other bills to ward the agencies away from certain regulatory action. The most notorious of these efforts sought to restrain the then-activist Federal Trade Commission (FTC) from investigating and regulating the used car and funeral industries. ${ }^{36}$ Congress passed specific riders precluding spending for such activities and requiring agency rules to be submitted to Congress for review before becoming effective.

By the time the Supreme Court put an end to the legislative veto game, Congress and the courts were facing a more vigorous and directed assault on the administrative state-the Reagan Revolution.

Reagan's first shot was across the bow, gaining everybody's attention. Within weeks after taking office, President Reagan froze all regulations proposed in the final days of the Carter Administration. ${ }^{37}$ A Task Force on Regulatory Relief, headed by Vice President George Bush, began studying federal regulatory efforts. In 1981, Task Force member James C. Miller, III wrote:

[W]e expect President Reagan to increase significantly the pace of reform in the social regulatory areas. One reason for such an impression is that despite the rhetoric, President Carter and the Congress really did little to address this issue during the past four years. President Reagan seems determined to bring about substantial change. ${ }^{38}$

Also within the first month of his presidency, Reagan signed Executive Order 12,291, requiring cost-benefit evaluation of major regulatory proposals. ${ }^{39}$ Only regulations having a net benefit-and the greatest possible net benefit for the regulatory goal-would get the President's stamp of approval. The President's Office of Management and Budget (OMB) was given power to review the agency

34 Craig, Chadha at 40 (cited in note 32 ).

ss 462 US 919 (1983).

${ }^{36}$ See Craig, Chadha at 133, 216-19 (cited in note 32).

${ }^{37}$ Exec Order 12,291, 31981 CFR 127, 131-32 (1982), reprinted in 5 USC $\S 601$ app (1988).

33 James C. Miller, III and Jeffrey A. Eisenach, Regulatory Reform Under Ronald Reagan, in Wayne Valis, ed, The Future Under President Reagan 89, 98 (Arlington House, 1981).

${ }^{39}$ Note, Executive Orders 12,291 and 12,498: Usurpation of Legislative Power or Blueprint for Legislative Reform?, 54 Geo Wash L Rev 512, 515 (1986). 
cost-benefit evaluations and, in effect, to quash unsatisfactory regulations. ${ }^{40}$

Although not signed by President Reagan until a month before his second inauguration, Executive Order 12,498 represented yet another significant thrust in this effort to take control of the agencies. ${ }^{41}$ It required OMB review of proposed regulations to "ensure that all regulatory actions are consistent with the goals of the agency and the Administration." 42

While the executive orders did nothing to roll back the administrative state, they stopped many new efforts in their tracks. By 1986, one-third of all federal regulatory proposals reportedly were vetoed or held up by OMB, including over half of the Environmental Protection Agency (EPA) proposals in one three year period, and almost eighty percent of the proposed hazardous waste regulations. ${ }^{43}$ The executive orders were also the first effort, almost completely successful, to bypass Congress in setting priorities and shaping the specifics of administrative agency actions.

The regulatory freeze also interrupted the continuity of agency action that usually extends from one administration to the next. Typically, civil service employees and the higher level policymakers who remain for at least several months into a new administration continue the direction and policies of the previous administration. This "continuity" once prompted a frustrated President Kennedy to respond to a request for his assistance by saying, "I can do it, but I don't know if the government can." "44 A Carter Administration official made a similar observation about controlling the federal bureaucracy: "It's like steering a supertanker. You may put the wheel over hand, but it's not going to turn on a dime." ${ }^{.45}$ But James Miller, the future OMB Director who joined the Reagan Administration as OMB Administrator of Regulatory Affairs, did not complain about the government being a clumsy supertanker once Executive Order 12,291 was signed. Reflecting on the redistribution of power in the administrative state brought about by President Reagan—and the OMB-he said, "[I]f you're the toughest

\footnotetext{
30.

${ }^{40}$ Id at $515 \mathrm{n} \mathrm{19}$, citing Exec Order 12,291 $\S 3(\mathrm{c})(2), 3(\mathrm{f}), 6(\mathrm{a})(2), 31981 \mathrm{CFR}$ at $129-$

${ }^{11}$ See 31985 CFR 323 (1986), reprinted in 5 USC $\$ 601$ app (1988).

2 Note, 54 Geo Wash L Rev at 520 (cited in note 39), quoting Exec Order 12,498 § 1(b), 3 1985 CFR at 323.

${ }^{43}$ Oliver A. Houck, President $X$ and the New (Approved) Decisionmaking, 36 Am U L Rev 535, 540-42 (1987).

14 Tolchin and Tolchin, Presidential Power at 79 (cited in note 2).

${ }^{45}$ Id at 58 (quoting Rick Neustadt).
} 
kid on the block, most kids won't pick a fight with you. The executive order establishes things quite clearly."46

President Reagan's initial freeze on new regulations not only broke the continuity with the previous administration, it also bought the Reagan Administration time to place new people in the key agency positions under executive control. Many of these appointees took office with the avowed goal of abolishing the agency or redefining the regulatory mandate issued by Congress. Their stated goals did not interfere with Senate confirmation, partly because the Senate had also heard the message sent by the 1980 voters, and partly because the means by which the new policymakers would achieve their stated goals were not widely discussed during confirmation hearings. Terrel $\mathrm{H}$. Bell, for example, President Reagan's first Secretary of Education, personally lobbied Congress to abolish the department. ${ }^{47}$ Years after his service in the cabinet, he observed in a memoir, "Jefferson also advocated that the states carry the ball on education, so perhaps he did not turn over in his grave when I presented the draft legislation to abolish [the Department of Education]." ${ }^{48}$ When Bell retired, William J. Bennett, President Reagan's chosen successor at Education, also came to the agency favoring its abolition. ${ }^{49}$

Like Terrel Bell, the new director of the Interior Department's Office of Surface Mining (OSM) - the agency that had forced coal companies to restore the natural landscape wasted by strip mining $^{50}$ - was not a supporter of the agency he was to lead. He and his assistant had been active in bringing legal challenges to the federal strip mining law. In the Reagan Administration, they were charged with enforcing the law, even as their arguments against it were being heard in the Supreme Court. ${ }^{\text {s1 }}$ When the Court decided the challenge against the coal companies, an Interior Department lawyer called to tell the assistant director that Interior's defense of the strip mining law had won. The assistant director responded, "No. We lost." 52 Interior Secretary James Watt had pledged to undo the OSM regulations, which he referred to as a "bureaucratic

\footnotetext{
${ }^{46}$ Houck, 36 Am U L Rev at 549 (cited in note 43). 1988).

4 Terrel H. Bell, The Thirteenth Man: A Reagan Cabinet Memoir 93-95 (Free Press,

48 Id at 92.

19 Barbara Vobejda, Bennett Leaves Post He Endowed with New Visibility, Influence, Wash Post A4, col I (Sept 20, 1988).

${ }^{50}$ Dale Russakoff, The Unforcer, Wash Post Al, col 1 and A8, col 1 (June 6, 1982).

${ }^{51}$ Id at A8.

${ }^{32}$ Id.
} 
nightmare." But without changing a single word of the strip mining law, the OSM assistant director was later able to boast, "We tore this agency to hell." 53

The Legal Services Corporation became the epic of the Reagan years. President Reagan and his long-time legal advisor and eventual Attorney General, Edwin Meese, came into office with long and painful memories of the hardiness of the Legal Services Corporation, stemming from their days in California. As Governor, Ronald Reagan had often felt the interfering sting of the feisty public interest lawyers who, financed by the Corporation's predecessor, the Office of Economic Opportunity, had blocked many of his initiatives. These lawyers' court victories forced Governor Reagan's administration to restore cuts totalling $\$ 210$ million to the Medicaid program and to guarantee farm laborers the minimum wage. The administration was also told that certain working conditions for women and children could not be tolerated. ${ }^{54}$ The newly elected Reagan national team saw the Corporation as a hotbed of liberal lawyers dedicated to funding politically-oriented public impact cases. These lawyers, they expected, would protect and defend the very programs and regulatory activities that the administration had promised to end. The Corporation, and its "ideological ambulance chasers," $" 55$ as then-Governor Reagan termed the lawyers, had to go. ${ }^{56}$

Unfortunately for the President, the Corporation had a greater constituency than the Administration had imagined. When Reagan's appointees to the Corporation tried to eliminate its functions without legislation, Congress implemented specific performance functions that the Corporation had to administer. Congress legislated mandatory spending levels and, by inserting substantive provisions in the authorizing and appropriations bills, provided for near micro-management of the Corporation's activities by Congress and its committees. Needless to say, Congress resisted direct efforts to kill off the Corporation. ${ }^{37}$ When the chairman of the Corporation told a meeting of its prime supporters, the American Bar Association, that the Corporation should be dissolved, his message

s3 Id.

s4 Elizabeth Drew, Legal Services, New Yorker 97, 99 (Mar 1, 1982).

ss Id.

${ }^{56}$ See Fred Barbash, Administration Strongly Defends Abolishing Legal Services Corp., Wash Post A8, col 4 (June 9, 1981).

${ }^{37}$ See William Chapman, Legal Services Unit Survives Senate Vote, Wash Post A2, cols 5-6 (Nov 14, 1981); and House Approves $\$ 14$ Billion for Federal Agencies, Wash Post A4, col 2 (July 2, 1987). 
fell on deaf ears. ${ }^{58}$ The ABA persuaded Congress to save the Corporation, and it still exists.

\section{Resolving the Power Struggle}

It is not clear that Congress would have frustrated President Reagan's deregulation initiative had he sought legislative cooperation. As indicated above, Congress had also read the political tea leaves; in its early calls for less government, the Administration was stating the views of the people. With the exception of a few issues such as the Legal Services Corporation, Congress might well have backed President Reagan's proposals for reducing the size of the administrative state.

But for reasons not apparent, the Administration decided to go it alone in accomplishing most of its regulatory agenda. Undoubtedly, it wanted to save political capital for more important battles with Congress-planned cuts in taxes and domestic programs were to consume a lot of the Administration's good will. Perhaps the Administration decided to risk resistance to unilateral deregulation rather than give Congress the opportunity to slow down or reshape the deregulatory proposals. Whatever the reasons, very few of Reagan's proposals were offered for legislative approval.

Many of Reagan's unilateral initiatives found their way into court, leaving the judicial branch to resolve the question of who controls the agencies and departments of the federal government. The executive won some of these challenges, but lost many of them, for several reasons. In some cases, the zealous deregulators had acted hastily or arbitrarily, violating the APA. In Public Citizen $v$ Steed ${ }^{59}$ for example, the D.C. Circuit held that the National Highway Traffic Safety Administration's (NHTSA) suspension of the treadwear grading requirements for motor vehicle tires had been "arbitrary and capricious." The suspension clearly ran afoul of what Congress had commanded NHTSA to do. The agency conceded that, from a consumer standpoint, the most meaningful characteristic of the tire-grading program mandated by Congress in the National Traffic and Motor Vehicle Safety Act ${ }^{60}$ was the treadwear grading requirement. ${ }^{61}$ NHTSA could not cogently explain the suspension, and demonstrated that it had failed to give

\footnotetext{
${ }^{68}$ Who Needs Lawyers?, Wash Post C6, col 1 (Feb 15, 1987).

s9 733 F2d 93, 105 (DC Cir 1984).

60 15 USC $\S 1423$ (1982).

61 Public Citizen, 733 F2d at 94.
} 
serious attention to other measures that could correct the problems purportedly underlying the suspension.

In 1981, pursuant to Executive Order 12,291, the new EPA Administrator, Anne Gorsuch, wrote the OMB that certain regulations covering hazardous waste facilities, proposed just as President Reagan was entering office, were encountering substantial objections in the regulated community. ${ }^{62}$ After these regulations became effective, she suspended them. This decision constituted a promulgation of a new regulation, subject to the notice and comment requirements of the APA. Because the EPA ignored these requirements, the Administrator's action was invalid..$^{63}$ Of course, it took years for the suspension to be rejected-the court of appeals decision was issued in July of 1983, two years after the suspended regulations became effective-wasting resources that could have been saved had the agency followed the APA. It is very possible that the Administration could have achieved its end even faster and more effectively by asking Congress to repeal the regulations.

Perhaps the most famous example of arbitrary unilateral deregulation is the State Farm case, ${ }^{64}$ in which Secretary of Transportation Drew Lewis postponed and then rescinded-within months of taking office-an automobile safety regulation that would have required the installation of passive restraints in all new automobiles by 1984 . The stated reason for this rescission was the inability to predict that the installation of the particular passive restraint proposed-automatically fastening seatbelts that were detachable from the car to provide for emergencies-would in fact increase the number of drivers protected by passive restraints. The Secretary contended that many car owners would disconnect the automatic seatbelts from the car entirely-his logic, apparently, being that people who dislike the trouble of fastening manual seatbelts would take the time to permanently detach automatic belts.

The court of appeals heard a challenge to the rescission and rejected the Secretary's decision as arbitrary because the Secretary failed to show that rescission (which, like promulgation, is governed by the APA) was justified. ${ }^{65}$ In the appellate court's view, there was "not one iota of evidence to support" the claim that the

\footnotetext{
${ }^{62}$ Environmental Defense Fund, Inc. v Gorsuch, 713 F2d 802, 808 (DC Cir 1983).

${ }^{63}$ Id at 818.

64 State Farm Mutual Automobile Insurance Co. $v$ Department of Transportation, 680 F2d 206 (DC Cir 1982), vacated and remanded, 463 US 29 (1983).

${ }^{63}$ Id at 230.
} 
installation of passive seat belts would not increase seat belt usage. ${ }^{66}$

The Supreme Court agreed that the rescission had not been justified. ${ }^{67}$ It held that the agency had a responsibility to explain deregulatory actions because "the forces of change do not always or necessarily point in the direction of deregulation." 68 While it did not agree with all of the court of appeals's reasoning, the Court derailed the deregulators; State Farm became the standard for measuring and restricting such summary deregulation. The Administration wasted two years litigating a matter that probably could have been resolved efficiently if the President, who was popular and had a clear deregulatory mandate, had directly asked Congress to approve the change. State Farm was a discomforting precedent that made the entire cause of agency reform more difficult.

Center for Science in the Public Interest $v$ Department of the Treasury ${ }^{68}$ is yet another example of the Administration's tactic of deregulating in the least efficient way possible. The Federal Alcohol Administration Act directed the Treasury Department to require alcoholic beverage manufacturers to list ingredients on labels. Pursuant once again to Executive Order 12,291, less than five months after President Reagan's inauguration the Treasury Department revoked certain ingredient disclosure regulations that just a year before it had been "convinced" were "of real value." The Treasury provided no reasonable explanation for its decision to rescind ${ }^{70}$ and therefore the federal district court held that it had violated the APA.

But the Center for Science saga did not end there, just as the missteps of the deregulators did not stop at ignoring procedural requirements. The Administration often overstepped the substantive limits of its delegated power. In Center for Science, for example, the deregulatory decision clearly violated the substantive mandate set down by Congress: the agency looked at the economic costs to the industry of complying with the regulation, as mandated by Executive Order 12,291, even though the terms of the Act mandated consumer protection notwithstanding costs to the industry. ${ }^{71}$ The court decision striking down the rescission, as in State

${ }^{63}$ Id at 231.

67 Motor Vehicle Manufacturers Association of the United States v State Farm Mutual Automobile Insurance Co., 463 US 29, 56-57 (1983).

68 Id at 42 .

so 573 F Supp 1168 (D DC 1983).

7o Id at $1172,1177$.

71 Id at 1174-75, 1179, citing 27 USC $\$ 205$ (e) (1982). 
Farm, did not issue until some fifteen months after the rescission. And so, in the name of efficiency, the Administration wasted time and resources.

It took three years for the federal government's new labeling regulations, formulated in response to the earlier court decision, to obtain judicial approval. The new regulations-actually, deregulations, in that they (like the 1981 changes) rescinded the earlier ingredient disclosure rules-were upheld in 1986. The court of appeals held, "[The federal government]'s efforts to explain its turnabout have hardly been exemplary, but the record developed, the explanation provided, and the alternatives considered combine to meet the standard of reasoned decisionmaking."72

Agencies exceeded the substantive limits on their power in other cases, prompted by the Administration's efforts to avoid executing mandatory regulatory obligations. In Farmworker Justice Fund, Inc, $v$ Brock, ${ }^{73}$ for example, the court held that the Secretary of Labor exceeded his authority when he refused to issue a field sanitation standard requiring access to toilets and drinking water. The court rejected the Secretary's arguments for not issuing the standard, including variations of a "faith in federalism" argument, which suggested that the states could be trusted to act if the federal government left the problem alone. The Secretary also claimed that Congress did not have the right to issue regulations covering state social welfare problems.

Emphasizing its disapproval of the Secretary's inaction (as well as the inaction of previous Secretaries), the court of appeals observed that the Farmworker Justice Fund case was even worse than the wrongful decision not to regulate in Public Citizen (where the court had said, "It is hard to imagine a more sorry performance of a congressional mandate ...."). ${ }^{74}$ As in Public Citizen, the court held that the Secretary lacked the authority to withhold action. Accordingly, it ordered the Secretary to issue a field sanitation standard within thirty days. ${ }^{75}$

In Union of Concerned Scientists $v$ United States Nuclear Regulatory Commission, the Nuclear Regulatory Commission (NRC) attempted to lower safety standards for nuclear power plants by considering cost factors that the statute did not author-

${ }^{72}$ Center for Science in the Public Interest $v$ Department of Treasury, 797 F2d 995, 1004 (DC Cir 1986) (footnote omitted).

${ }^{73} 811$ F2d 613 (DC Cir 1987), vacated as moot, 817 F2d 890 (DC Cir 1987).

74 Public Citizen, 733 F2d at 105; and Farmworker Justice Fund, 811 F2d at 633.

75 811 F2d at 633 . 
ize it to take into account. ${ }^{76}$ In deciding whether to require a plant to install additional safety-enhancing features, the Commission looked at the costs of installation and maintenance, including facility downtime, construction delays, and the estimated resource burden on the NRC. ${ }^{77}$ The court determined that this unilateral attempt to implement a policy revision-motivated by concern for the costs imposed upon nuclear power plant operators-was invalid. Once again, if the Administration wanted the agency to be more sensitive to costs, and less sensitive to public safety, it could have taken up the issue directly with Congress. This would have allowed it to stay out of the courts and avoid ending up back at square one, two years after the final rule was proposed.

To be sure, some court challenges to unilateral deregulation were unsuccessful. In Natural Resources Defense Council v EPA, the EPA withdrew regulations governing vinyl chloride emissions, and the courts held this action to be within the bounds of the Clean Air Act. ${ }^{78}$ Interior Secretary James Watt revised the regulations promulgated under the Surface Mining Act with an eye toward increased flexibility in federal supervision of state regulatory programs, and many of the new regulations withstood challenges by the National Wildlife Federation. ${ }^{79}$

Even in the latter case, where the agency largely "won" the battle to deregulate autonomously, the fact that 113 issues related to the new scheme were litigated at the district court level alone ${ }^{80}$ makes one wonder whether the Administration truly won a victory at all. The "victory" may well have been a net loss if we consider the agency's litigation costs.

Consider also the Cheuron ${ }^{81}$ case, in which the EPA revised certain regulations for emissions covered by the Clean Air Act. The new regulations were designed to determine the permissibility of additional polluting units (generally, smokestacks) in industrial plants not by the amount of pollutants the individual unit would add to the atmosphere, but by whether emissions from the entire plant would increase (the "bubble" concept). The court of appeals vacated the regulations, and it took two years before the Supreme Court reversed the appellate opinion and established the validity

78824 F2d 108, 120 (DC Cir 1987).

7710 CFR $\$ 50.109$ (c) (1986).

${ }^{78} 804$ F2d 710 (DC Cir 1986).

79 National Wildlife Federation v Hodel, 839 F2d 694, 702, 716-719 (DC Cir 1988).

${ }^{80}$ Id at 702 .

${ }^{81}$ Chevron, U.S.A. $v$ Natural Resources Defense Council, 467 US 837 (1984), reversing 685 F2d 718 (DC Cir 1982). 
of the "bubble concept" of plant emissions. This concept could not have been challenged if it had been expressly approved by an act of Congress.

\section{Court Battles are Not a Solution}

Even though the courts can resolve some suits challenging agency action, their ability to act as referees does not solve the problem of executive overreaching. Not every case concerning the scope of an agency's statutory mandate lends itself to a "plain meaning" analysis. After Chevron, which determined the role of the courts where these statutes are unclear, an agency's interpretation of the scope of permissible action is shielded from judicial intrusion, so long as the agency's interpretation is a plausible reading of an ambiguous statute.

This point is demonstrated by Animal Protection Institute of America $v$ Hodel, ${ }^{82}$ which concerned the Wild Free-Roaming Horses and Burros Act. This Act authorized the Secretary of the Interior to conduct an "adopt-a-horse" program in which individuals could adopt wild horses to prevent their "capture, branding, harassment or death." 83 The Secretary interpreted the Act to allow adopters who provided one year of humane treatment and care to then use the adopted animals for commercial purposes. The court rejected this interpretation, finding that it frustrated the clear purpose of the statute's one year probationary period-that adopters be screened to ensure that they intended to care humanely for adopted animals. ${ }^{84}$

Given the Cheuron standard of judicial review, it is possible that other courts applying the Wild Horses Act would not have found Congress's intent absolutely clear. Indeed, another court applying Chevron's analysis might have found the statute ambiguous and upheld the Secretary's construction as reasonable. Just as Animal Protection Institute could have been decided for the Secretary, Center for Science, the alcohol ingredient labeling case, could have been decided against the Treasury. The second rescission of the disclosure rules was eventually upheld, but could reasonably have been interpreted as contravening the statutory mandate that the Secretary of the Treasury promulgate regulations "as will provide the consumer with adequate information as to the

\footnotetext{
${ }^{82} 860$ F2d 920 (9th Cir 1988).

${ }^{83}$ Id at 922 .

s4 Id at 927 .
} 
identity and quality of the products . . . " 85 Indeed, the district court's reading of Congress's clear intent was contrary to that of the appellate court. The district court maintained:

Congress announced that the Department had the authority to issue regulations requiring producers of alcoholic beverages to adequately inform the consumer of the identity and quality of the products .... It did not condition such a grant of authority with a proviso that the regulations could be withdrawn if the costs to the industry turned out to be too high. ${ }^{86}$

The court of appeals specifically stated, however, that the government, in promulgating the new rescission, "properly concluded that the costs of ingredient labeling could be considered."

My intent is not to question the judgment of the courts, but to show that the more Congress and the President rely upon the courts to resolve their indecision over who should do what, the harder it becomes for courts to avoid doing-or interfering with-the job Congress gave to the agencies. The role of the courts is properly limited to providing consistent and reasoned solutions to the disputes facing the other branches.

The Reagan Administration's success in deregulating through the backdoor is hard to evaluate, precisely because the courts properly looked at each case separately and apart from the overall deregulatory strategy the Administration pursued. In Natural Resources Defense Council v EPA, National Wildlife Federation $v$ Hodel, and eventually, Center for Science, the courts allowed President Reagan to achieve deregulation without the approval of Congress. On the other hand, Environmental Defense Fund $v$ Gorsuch, State Farm, the challenge to the first rescinding regulation in Center for Science, Farmworker Justice Fund, and Union of Concerned Scientists are but a few examples of the costly legal battles lost by the Reagan deregulators. An unambiguous result of this mixed scorecard of legal battles, as Professor Kenneth Culp Davis told the Forty-Sixth Judicial Conference of the District of Columbia Circuit in 1985, is "the gradual movement . . . in the direction of more conflicts and more confusion . . .." He added, "[T]he direction of movement is overwhelmingly away from clarification."

senter for Science, 797 F2d at 997.

se Center for Science, 573 F Supp at 1174.

87797 F2d at 1002.

${ }^{88}$ Kenneth Culp Davis, Proceedings of the Forty-Sixth Judicial Conference of the District of Columbia Circuit, 111 FRD 91, 174 (1985). 


\section{Prospects for Statutory Reform}

The cursory nature of this review of ten years of administrative law decisions has given short shrift to many of the tools that courts are obliged and instructed to use in reviewing administrative agency decisions. I have referred to the constitutional separation of powers principles that require the courts to give primary deference to the clear instructions of Congress when it acts in its constitutional capacity, but I have given little attention to statutory limits on judicial review. The statutory basis for most judicial review of agency decisions is the Administrative Procedure Act, passed in 1946. There has been little discussion of the efficacy of the APA, and it has seldom been amended. Given the great growth of the administrative state since 1946, the APA could well stand a thorough revision. Unfortunately, previous efforts to change the APA proved controversial because they were aimed at achieving a specific result or overturning a specific court holding.

The "Bumpers Amendment," 89 for example, would have altered the APA's standard of review to eliminate the presumption that agency rules or regulations are valid. This overly ambitious proposal would have created chaos in the courts, forcing them to review the extensive testimony and numerous exhibits presented to the agencies in connection with many of the thousands of rules issued by regulatory agencies each year. (The proposal also would have vacated the reasoning, if not the holding, of Cheuron, where the Court insisted that the agencies be given great deference.)

The "Simpson Proposals" also would not truly have reformed the decisionmaking process. These proposals would have authorized any United States Court of Appeals to review regulations currently reviewable only by the Court of Appeals for the District of Columbia Circuit. ${ }^{90}$ Complex agency cases would have been placed in the hands of judges unfamiliar with the bureaucracy, leaving unresolved the fundamental tension that is the source of increasing litigation and confusion in the administrative state-the inability of the executive and legislative branches to cooperate, or at least to avoid conflict.

Because of the recurring suspicion between the two political branches, there is little reason to hope for the easing of this tension. And as long as this tension exists, a basic charter like the

8s Amend No 535, S 1477, 96th Cong, 2d Sess (June 21, 1979), in 125 Cong Rec 23478 (Sept 7, 1979).

so S 2849, 98th Cong, 2d Sess (June 25, 1984), in 130 Cong Rec 8923 (June 29, 1984). 
APA, governing the method by which virtually all agency decisions are made, cannot be thoroughly and dispassionately appraised.

\section{CONCLUSION}

Some critics argue that deregulation has been carried too far. They point to the airline and pharmaceutical industries as examples of the need for more, not less, government regulation of the private sector. I need not climb into that political thicket to make my point-that changes in the administrative state are best accomplished when the executive and legislative branches cooperate. While either Congress or the President can make some progress alone, significant expansion or contraction of the quantity of regulation in our society is best accomplished when all the policymakers are in harmony on a desired result. Such coordinated action would greatly simplify the judicial task, would render administrative law more manageable to teach and learn, and would give those subject to regulation some guidance as to the shape and scope of their burdens. Most importantly, coordinated policymaking would be faithful to the not-at-all-simple constitutional plan whereby the powers of the three branches of government are separate, but not at all equal. 
